\title{
MONOSOMIC ANALYSIS IN WHEAT*
}

\author{
M. P. SINGH \\ Division of Genetics, Indian Agricultural Research Institute, \\ New Delhi-12, India
}

Received 13.ii.67

\section{INTRODUCTION}

Certain aneuploids, particularly nullisomics, monosomics and trisomics, find a place in plant breeding because of their value in locating genes on different chromosomes. The method is particularly useful in polyploids, where monosomics and nullisomics are viable. The use of monosomic series has made it possible to locate both genes with major and those with minor effects. The value of aneuploid analysis in determining the mode of inheritance of different characters, particularly awning and growth habit in some varieties of bread wheat has already been demonstrated (Unrau, I950; Heyne and Livers, I953; Sears, I953, I954; Sikka et al., I956; Kuspira and Unrau, I957; Tsunewaki and Jenkins, I96 I; Tsunewaki, I 966, etc.). The present studies were designed to study the genetics of these characters in the wheat variety Yaqui-53.

\section{MATERIALS AND METHODS}

Yaqui-53 is a derivative of New Thatcher $\times$ Kenya. It is short tipped, medium height and early in maturity. Chinese Spring is " hooded beardless", medium-tall and matures late. Using monosomics as the female parent, each of the $2 \mathrm{I}$ monosomic lines of Chinese Spring was crossed with Yaqui-53. A cross between normal Chinese Spring and Yaqui-53 was also attempted. The chromosome number of all the $F_{1}$ hybrids was determined in p.m.c's and seeds from cytologically confirmed monosomics were collected separately. $F_{2}$ progenies of all the 2I monosomic lines were screened for awnedness and classified as fully awned or half awned, tipped or awnless. The first two and latter two types were grouped together for statistical analyses. The heading dates of all the plants were noted and mean values obtained when a minimum of 75 per cent. of plants eared in each $F_{2}$ progeny. The mean heading days of all the $2 \mathrm{I}$ monosomic $\mathrm{F}_{2}$ lines were compared with disomic hybrids and the departure in each case was recorded separately. Analysis of variance followed by a " $t$ " test was applied in order to find the difference between monosomic and disomic line and also to mark the "critical" monosomic lines.

\section{OBSERVATIONS}

\section{Growth habit}

The heading dates of different monosomic crosses, the normal disomic cross and both the parents, Yaqui-53, and Chinese Spring are shown in table $\mathrm{I}$. The mean heading dates of the normal cross were

* Part of a thesis submitted to the Post-Graduate School, I.A.R.I., New Delhi, in partial fulfilment of the requirements for a Ph.D. Degree. 
compared with other monosomic crosses and the deviation observed is summarised in table $\mathrm{I}$. The observations indicated that Yaqui-53 is early in earing (92 days) and Chinese Spring late by II-I 2 days. Most of the monosomic lines were intermediate in earing. $F_{1}$ 's monosomics for chromosome $5 \mathrm{D}$ (XVIII) showed later heading and in mono- $5 \mathrm{~B}(\mathrm{~V})$ cross earing was hastened by 6-7 days. Analyses of

TABLE I

Days to heading

(Chinese monosomics $\times$ Yaqui-53)

\begin{tabular}{|c|c|c|c|c|}
\hline Material & $\begin{array}{l}\text { Total No. } \\
\text { of plants }\end{array}$ & $\begin{array}{l}\% \text { of plants } \\
\text { eared }\end{array}$ & $\begin{array}{l}\text { Mean No. } \\
\text { of days to } \\
\text { heading }\end{array}$ & $\begin{array}{c}\text { Deviation } \\
\text { from } \\
\text { disomic cross }\end{array}$ \\
\hline $\begin{array}{l}\text { Chinese Spring } \\
\text { Yaqui-53 } \\
\text { Chinese Normal } \times \text { Yaqui-53 } \\
\text { IA } \times \text { Yaqui-53 } \\
2 \mathrm{~A} \times \text { Yaqui-53 } \\
3 \mathrm{~A} \times \text { Yaqui-53 } \\
4 \mathrm{~A} \times \text { Yaqui-53 } \\
5 \mathrm{~A} \times \text { Yaqui-53 } \\
6 \mathrm{~A} \times \text { Yaqui-53 } \\
7 \mathrm{~A} \times \text { Yaqui-53 } \\
\mathrm{B} \times \text { Yaqui-53 } \\
2 \mathrm{~B} \times \text { Yaqui-53 } \\
3 \mathrm{~B} \times \text { Yaqui-53 } \\
4 \mathrm{~B} \times \text { Yaqui-53 } \\
5 \mathrm{~B} \times \text { Yaqui-53 } \\
6 \mathrm{~B} \times \text { Yaqui-53 } \\
7 \mathrm{~B} \times \text { Yaqui-53 } \\
\text { ID } \times \text { Yaqui-53 } \\
\text { 2D } \times \text { Yaqui-53 } \\
3 \mathrm{D} \times \text { Yaqui-53 } \\
4 \mathrm{D} \times \text { Yaqui-53 } \\
5 \mathrm{D} \times \text { Yaqui-53 } \\
6 \mathrm{D} \times \text { Yaqui-53 } \\
\text { 7D } \times \text { Yaqui-53 }\end{array}$ & $\begin{array}{l}203 \\
239 \\
167 \\
150 \\
162 \\
150 \\
157 \\
147 \\
151 \\
157 \\
151 \\
107 \\
150 \\
164 \\
136 \\
170 \\
146 \\
157 \\
159 \\
162 \\
150 \\
160 \\
146 \\
156\end{array}$ & $\begin{array}{l}75 \cdot 72 \\
84 \cdot 17 \\
78 \cdot 44 \\
82 \cdot 67 \\
82 \cdot 10 \\
86 \cdot 00 \\
76 \cdot 43 \\
76 \cdot 87 \\
82 \cdot 11 \\
80 \cdot 89 \\
75 \cdot 50 \\
73 \cdot 65 \\
82 \cdot 00 \\
78 \cdot 05 \\
91 \cdot 18 \\
74 \cdot 94 \\
80 \cdot 14 \\
78 \cdot 34 \\
80 \cdot 50 \\
82 \cdot 00 \\
81 \cdot 33 \\
72 \cdot 63 \\
86 \cdot 98 \\
81 \cdot 41\end{array}$ & $\begin{array}{r}104 \cdot 4 \\
92 \cdot 2 \\
99 \cdot 6 \\
101 \cdot 4 \\
102 \cdot 2 \\
101 \cdot 4 \\
102 \cdot 6 \\
102 \cdot 4 \\
101 \cdot 3 \\
99 \cdot 0 \\
102 \cdot 3 \\
99 \cdot 0 \\
102 \cdot 4 \\
101 \cdot 6 \\
93 \cdot 0 \\
102 \cdot 1 \\
99 \cdot 3 \\
101 \cdot 4 \\
100 \cdot 8 \\
100 \cdot 1 \\
99 \cdot 2 \\
106 \cdot 4 \\
100 \cdot 6 \\
100 \cdot 6\end{array}$ & 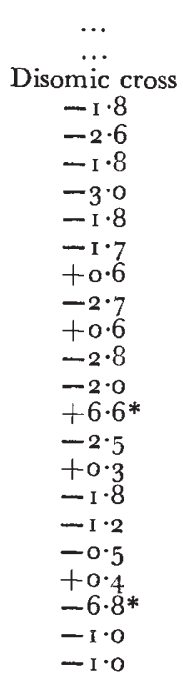 \\
\hline
\end{tabular}

* "Critical" lines showing maximum deviation. Significant at I per cent. level.

$(-)$ indicates later heading and $(+)$ earlier heading when compared to disomic.

the data from $\mathrm{F}_{2}$ observations indicated the presence of some factors for early maturity on chromosome $5 \mathrm{~B}(\mathrm{~V})$ of Yaqui-53. The heading date was significantly delayed in mono-5D. The delay in heading in mono- $5 \mathrm{D}$ was maximum, here the plants were still green, while in other lines they were ready for harvesting.

\section{Awning}

Yaqui-53 is an apically tipped variety which shows " tipped I" type of awn expression, according to the classification of Watkins and Ellerton (1940). In all the monosomic lines, $F_{1}$ plants were almost awnless, except mono- $4 \mathrm{~B}$ and $6 \mathrm{~B}$, where somewhat more tipping was present. The $F_{2}$ population, grown from seeds collected from $F_{1}$ 
monosomics, showed a complete range of awn types, with fully awned, half-awned, awnletted and awnless plants. A similar type of segregation was observed in the normal cross of Yaqui-53 and Chinese Spring. The number of awned plants was high in monosomic line $4 \mathrm{~B}$ and $6 \mathrm{~B}$.

TABLE 2

Genetics of awning

(Chinese monosomics $\times$ Yaqui-53)

$\mathrm{F}_{2}$

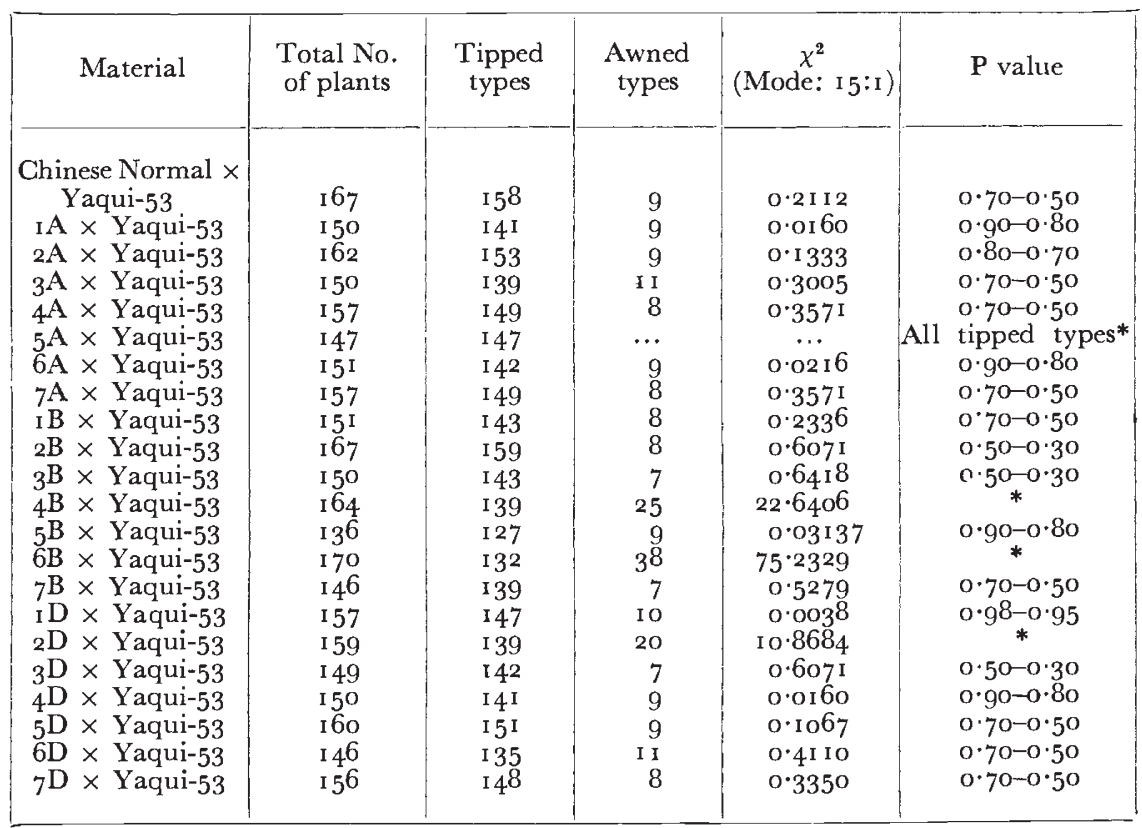

* Monosomic lines showing high deviation from the normal cross.

Not a single awned plant was recorded in monosomic line $5 \mathrm{~A}$. Different segregation ratios were tried, but only i5 awnless: I awned gave a satisfactory fit. The data thus obtained are presented in table 2 .

\section{Growth habit}

\section{DISCUSSION}

Among the $2 \mathrm{I}_{2}$ monosomic lines of Yaqui-53, mono-5D (XVIII) showed significant later heading than the disomic. As reviewed by Tsunewaki and Jenkins (I96r, I962) the growth habit of common wheat is mainly controlled by genes belonging to three allelic series $S g_{1}, S g_{2}$ and $S g_{3}$ located on chromosome $5 \mathrm{D}$ (XVIII), $5^{\mathrm{A}}$ (IX) and 2A (XIII). But Chapman and Riley (I966) have redesignated Chromosome XIII as $2 \mathrm{~B}$ and II as $2 \mathrm{~A}$. All winter varieties carry winter habit alleles $S g_{1}, S g_{2}$ and $S g_{3}$. They suggested that some late spring varieties carry the semi-winter habit alleles $S g_{1}{ }^{c}, S g_{2}{ }^{c}$ and $S g_{3}$. 
Yaqui-53 is an early maturing variety and Chinese Spring is semiwinter type. Among the 2I $\mathrm{F}_{2}$ lines of Yaqui-53 cross, mono-5D (XVIII) showed significant later heading than the disomic. The delay in heading caused by chromosome ${ }_{5} \mathrm{D}$ (XVIII) of Yaqui- 53 in Chinese Spring could be due to presence of gene for lateness, which might be ineffective in hemizygous condition or due to the absence of semi-winter gene $S g_{1}{ }^{c}$ of Chinese Spring. The significant early heading date observed in ${ }_{5} \mathrm{~B}(\mathrm{~V})$ cross could be due to presence of dominant gene for spring habit and this may be epistatic in its action (table I).

The haploid genotype proposed by Tsunewaki (I966) for variety Chinese Spring is: $S g_{1}{ }^{c}, S g_{2}{ }^{c}$ and $S g_{3}$. Taking into consideration this genotype, normal segregation pattern and deviation in critical monosomic lines, it is evident that Chinese Spring differs from Yaqui-53 in two major genes of Spring growth habit, located on chromosome ${ }_{5} \mathrm{~B}$ and $5 \mathrm{D}$. The analyses of $\mathrm{F}_{1}$ and $\mathrm{F}_{2}$ data indicated that even hemizygous condition in $5_{5} \mathrm{~B}$ cross did not cause any delay in heading. If this gene on chromosome ${ }_{5} \mathrm{~B}$ of Yaqui-53 is designated as $S g_{5}$, then the probable haploid genotype for growth habit will be: $S g_{1}(5 \mathrm{D}), S g_{2}{ }^{c}$ $(5 \mathrm{~A}), S g_{3}(2 \mathrm{~A}), S g_{5}(5 \mathrm{~B})$. It is interesting to note that all the three members of homoeologous group No. $5\left(5 \mathrm{~A},{ }_{5} \mathrm{~B},{ }_{5} \mathrm{D}\right)$ affect time of maturity, though with different intensity. Driscoll and Jensen (I 964 ) also reported that chromosome $5 \mathrm{~B}$ of selection $5075^{-a B}-2 \mathrm{~B}-2 \mathrm{I}$ possesses a gene for earliness. Sears (1 944, I 954) reported gene for earliness on chromosome $5^{\mathrm{B}}$, but it is evident that the gene carried by Yaqui- 53 on the same chromosome is more effective than the gene present in Chinese Spring.

Kuspira and Unrau (1957) suggested that two types of earliness genes are apparently operating $(a)$ those differentiating summer and winter growth habit as on chromosome $2 \mathrm{~A}$ (XIII) and $5 \mathrm{D}$ (XVIII), and $(b)$ those that modify the expression of genes to a greater or lesser extent. A chromosome ${ }_{5} \mathrm{~B}$ and $3 \mathrm{~A}$ of Thatcher, Hope and Timstein carry genes for hastening earliness. Thatcher is one of the donor parents in Yaqui-53, hence it is reasonable to assume that the same gene on chromosome $5 \mathrm{~B}$ is influencing the maturity. Another important point which emerges from the data is that the growth habit of bread wheat is governed by more than three loci. Critical monosomic analysis in more varieties of winter, semi-winter and spring types of wheat may further confirm the present results.

\section{Awning}

From the extensive studies of Watkins and Ellerton (1940) using conventional methods, and those of Sears (1944) using monosomic and nullisomic techniques, it is now clear that awn development in wheat is controlled by a series of recessive genes, designated $a_{1}, a_{2}, a_{3}$, etc., controlling awn promotion, and a set of dominant awn inhibitors $B_{1}$, $B_{2}$ and $H_{d}$ located respectively in chromosome ${ }_{5} \mathrm{~A}, 6 \mathrm{~B}$ and ${ }_{4} \mathrm{~B}$. Heyne and Livers (1953) have proposed a series of $A$ genes to explain awn 
development in different wheat varieties. A single recessive gene $a$ in the homozygous condition theoretically could produce full awns, if not inhibited by epistatic genes.

In the present monosomic studies, the $\mathrm{F}_{2}$ disomic populations, in crosses between Chinese Spring and Yaqui-53, segregated in a I $_{5}$ : I ratio of awnless or awnletted to awned and half bearded. However, the $\mathrm{F}_{2}$ population derived from mono- $4 \mathrm{~B}$ and $6 \mathrm{~B} \mathrm{~F}_{1}$ plants gave comparatively higher proportion of awned-plants, which indicated that tipped variety Yaqui-53 carries recessive alleles of awn inhibitors located on chromosome $4 \mathrm{~B}\left(H_{d}\right)$ and $6 \mathrm{~B}\left(B_{2}\right)$. There was no halfbearded or fully bearded plant in the progeny of mono-5 $\mathrm{A} \mathrm{F}_{1}$ plants, which indicates that Yaqui-53 carries a dominant awn inhibitory $B_{1}$ on this chromosome (tahle 2). The similarity in non-existence of awns, both in mono-5 $\mathrm{A}$ and disomic $\mathrm{F}_{1}$ plants, suggests the dominant nature of the $B_{1}$ factor.

Unrau (I950), O'Mara (I948) and Knott (I959) ascribed awnlettedness of Hymar, Marquis and Gabo respectively to the $B_{1}$ gene. Campbell and McGinnis ( $195^{8}$ ) reported that Redman carries another dominant awn inhibitor on chromosome ID (XVII), in addition to $B_{1}$. Okamoto ( 1960 ) has identified one awn suppressor on chromosome ${ }_{5} \mathrm{~B}$. Tsunewaki and Jenkins ( I96I) through monosomic and conventional gene analysis in common wheat, reported that the awnlettedness of wheat varieties Elgin and Jones Fife is controlled by the $B_{1}$ gene in chromosome $5 \mathrm{~A}$. They also obtained similar results in mono-4 $\mathrm{B}$ and $6 \mathrm{~B}$ cross where maximum deviation was recorded.

Excess of awned plants observed in $2 \mathrm{D}$ (XX) cross, allows an inference that some gene for awn development may be present. The digenic segregation obtained in the normal cross, does not explain the observations recorded in monosomic analysis, where four lines $\left({ }_{4} \mathrm{~B}, 5 \mathrm{~A}\right.$, $6 \mathrm{~B}$ and $2 \mathrm{D}$ ) showed significant departure from the expected ratio. It is probable that there are four factor pairs involved in segregation of awn types, which has not expressed due to complex interaction and small progeny size, so a tetragenic $\mathrm{F}_{2}$ ratio of 240:I 6 has changed to I5:I. Hence the proposed genotype for awning for Yaqui-53 will be:

$$
\begin{aligned}
& \text { Gene } \rightarrow h d h d: B_{1} B_{1}: b_{2} b_{2}: a_{2} a_{2} \\
& \text { Chromosome } \rightarrow 4 \mathrm{~B}(\mathrm{VIII}): 5 \mathrm{~A}(\mathrm{IX}): 6 \mathrm{~B}(\mathrm{X}): 2 \mathrm{D}(\mathrm{XX})
\end{aligned}
$$

\section{SUMMARY}

I. Yaqui-53 as the male parent, was crossed with all the 2 I identified monosomic lines of Chinese Spring.

2. Delayed heading in the mono-5D (XVIII) hybrid and significantly early heading in the mono-5B (V) hybrid indicated the presence of the recessive gene $s g_{1}$ and dominant gene $S g_{5}$ for growth habit on these chromosomes respectively.

3. The genotype for growth habit in Yaqui-53 may be: $s g_{1}(5 \mathrm{D})$, $S g_{2}{ }^{c}\left(5^{\mathrm{A}}\right), S g_{3}(2 \mathrm{~A})$ and $S g_{5}\left({ }_{5} \mathrm{~B}\right)$. 
4. In addition to the recessive alleles of, or absence of, the awn inhibitors $H_{d}$ and $B_{2}$ on chromosome, ${ }_{4} \mathrm{~B}$ (VIII) and $6 \mathrm{~B}(\mathrm{X})$, Yaqui-53 has the dominant awn inhibitor $B_{1}$ and recessive awn promoter $a_{2}$ located on chromosome $5 \mathrm{~A}(\mathrm{IX})$ and $2 \mathrm{D}(\mathrm{XX})$.

Acknowledgment.- The author expresses his sincere gratitude to Dr M. S. Swaminathan, Director, I.A.R.I., for his guidance and encouragement during the course of experiment. Thanks are also due to Dr H. K. Jain for his keen interest in the problem and to Dr E. R. Sears. from whom the monosomic lines of Chinese Spring were obtained.

\section{REFERENCES}

CAMPBELL, A. B., AND MCGINNIS, R. C. 1958. A monosomic analysis of stem rust reaction and awn expression in Redman wheat. Can. 7. Pl. Sci., 38, 184-187.

CHAPMAN, v., AND RILEY, R. I966. The allocation of the chromosomes of Triticum estivum to the $\mathrm{A}$ and $\mathrm{B}$ genomes and evidence on genome structure. Can. $\mathrm{F}$. Genet. Cytol., 8, 57-64.

DRISCOLL, C. J., and JENSEN, N. F. 1964. Chromosomes associated with waxlessness, awnedness and time of maturity of common wheat. Can. 7. Genet. Cytol., 6, 324-333.

HEYNE, E. G., AND LIVERS, W. 1953. Monosomic analysis of leaf rust reaction, awnedness, winter injury and seed colour in Pawnee wheat. Agron. 7., 45, 54-58.

кNOTT, D. R. 1959. The inheritance of rust resistance. IV. Monosomic analysis of rust resistance and some other characters in six varieties of wheats including Gabo and Kenya Farmer. Can. J. Pl. Sci., 39, 215-228.

KUSPIRA, J., AND UNRAU, J. 1957. Genetic analysis of certain characters in common wheat using whole chromosome substitution lines. Can. F. Pl. Sci., 37, 300-326.

окамото, м. 1960. An awn suppressor located on chromosome $5 \mathrm{~B}$. Wheat Information Service, II, 2-3.

o'mara, J. G. 1948. Awn inheritance in Triticum vulgare. Genetics, 33, 119.

SEARS, E. R. 1944. Cytogenetic studies with polyploid species of wheat. II. Additional chromosomal aberrations in Triticum vulgare. Genetics, 29, 237-247.

SE ARS, E. R. 1953. Nullisomic analysis in common wheat. Amer. Nat., 87, 245-252. SEARS, E. R. 1954. The aneuploids of common wheat. Mo. Agr. Exp. Sta. Res. Bull. 572.

Sikka, s. m., sWaminathan, M. s., Singh, M. P., AND Pal, B. P. 1956. Monosomic analysis of some characters in the wheat variety Cometa Klein. Indian $\mathcal{F}$. Genet., I6, 22-28.

TSUNEWAKI, K., AND JENKINS, B. G. 1961. Monosomic and conventional gene analysis in common wheat. II. Growth habits and awnedness. Fap. F. Genet., $36,428-443$.

TSUNEWAKI, K. 1962. Monosomic analysis of synthesized hexaploid wheats. Jap. 7. Genet., $37^{(2)},{ }_{15} 5^{-1} 68$.

TSUNEWAKI, K. I966. Comparative gene analysis of common wheat and its ancestral species. II. Waxiness, growth and awnedness. Jap. J. Bot., I9(2), I 75-229.

UNRAU, J. 1950. The use of monosomes and nullisomes in cytogenetic studies of common wheat. Sci. Agri., 3o, 66-89.

WATKINS, A. E., AND ElLERTON, s. 1940. Variation and genetics of the awn in Triticum. 7. Genet., 40, 243-270. 